\title{
The performativity of accounting: advancing a Posthumanist understanding
}

\author{
Ed Vosselman \\ Institute for Management Research, Radboud University, \\ Nijmegen, The Netherlands
}

\begin{abstract}
Purpose - The purpose of this paper is twofold. First, it seeks to articulate a framework for different conceptions of accounting's performativity. Second, it aims to advance a Baradian posthumanist understanding of accounting's performativity.

Design/methodology/approach - The paper traces different foundational conceptions of performativity and then articulates and substantiates different conceptions of accounting's performativity. It advances one of these conceptions by producing a Baradian posthumanist understanding of accounting's performativity.

Findings - Seven conceptions of performative accountings are articulated: accounting as a (counter) performative illocution; accounting as a performative perlocution; accounting as a self-fulfilling prophecy; accounting as an overflowing frame; accounting as a controlled relational agency; accounting as a mediator; and accounting as an exclusionary practice. It is argued how a posthumanist understanding of accounting as an exclusionary practice turns accounting from a world-knowing practice into a world-making practice. As such, it should be called to account.
\end{abstract}

Research limitations/implications - Posthumanist qualitative accounting research that conceives of accounting as an exclusionary practice focuses on how accounting is a material-discursive practice that intraacts with other practices, and on how there is a power-performativity in the intra-actions that locally and temporarily (re)produces meaningful positions for subjects and objects and the boundaries between them.

Practical implications - A posthumanist understanding teaches practitioners to be attentive to and accountable for the exclusions that come with accounting or, more generally, with measurement. Accounting raises ethical concerns.

Originality/value - This paper articulates different conceptions of accounting's performativity and makes the case for empirical non-anthropocentric examinations of accounting as an exclusionary practice.

Keywords Ethics, Performativity, Posthumanism, Intra-action, Material-discursive practice

Paper type Conceptual paper

I am no longer sure what counts as performative - Judith Butler, New York Times, July 10, 2019

(C) Ed Vosselman. Published by Emerald Publishing Limited. This article is published under the Creative Commons Attribution (CC BY 4.0) licence. Anyone may reproduce, distribute, translate and create derivative works of this article (for both commercial and non-commercial purposes), subject to full attribution to the original publication and authors. The full terms of this licence may be seen at http://creativecommons.org/licences/by/4.0/legalcode

The author would like to thank the Editor, Lukas Goretzki, and the three anonymous reviewers for their very constructive comments and guidance throughout the review process.
Performativity of accounting

Received 6 April 2021 Revised 31 August 2021

1 November 2021

4 December 2021

Accepted 6 December 2021 
QRAM

19,2

138

\section{Introduction}

What is performativity? As is reflected by the quote, one of the most prominent scientists involved in the development of this concept signals confusion about its meaning. There is a general understanding that performativity is a constitutive or generative power, a power not located in human beings, but a power of signs such as words and numbers to somehow participate in the constitution of the world. Yet, there apparently is confusion about the 'how' of this participation. How precisely do signs participate in the constitution of the world, in the constitution of a material reality?

In a critical review, Gond et al. (2016) observe that the notion of performativity has resonated throughout a number of disciplines, among them linguistics (Austin, 1962), philosophy (Barad, 2003, 2007; Derrida, 1979; Lyotard, 1984 [1979]; Searle, 1969), gender studies (Butler, 1988, 1993; 1997, 2010) and sociology (Callon, 1998; MacKenzie 2006a, $2006 \mathrm{~b})$, and that it is also visible in numerous sequels in organisation and management theory. They observe, however, that organisational theorists differently interpret the term and do not put too much effort in carefully relating their interpretations to foundational conceptions of performativity.

Accounting, being a phenomenon that comprises issues of measurement and valuation, is deeply implicated in issues of management and organisation. It is therefore remarkable that Gond et al. (2016) do not explicitly refer to studies that address accounting's performativity. A first quick scan of the accounting literature suggests that, similar to organisation theorists, accounting scholars who mobilise the concept of performativity also attach different meanings to it, and often are not very explicit in relating it to its foundations. In this paper, I set out to develop and to reflect on different possible conceptions of performative accounting, and to substantiate these conceptions with examples from extant accounting research. Moreover, I propose a further advancement of a hitherto underexplored posthumanist conception of performative accounting: that of accounting as an exclusionary practice. Guiding questions are: what are foundational conceptions of performativity? What foundational conceptions of accounting's performativity can be distinguished? And what further and relatively underexplored potential remains for studying accounting's performativity?

Early foundations of the concept of performativity are related to a so-called linguistic turn in the social sciences. In 1962, Austin distinguishes performative utterances from constative utterances in a speech act (Austin, 1962). In successive linguistic conceptions a turn is made from an utterance or a speech act to a discourse (Butler, 1988, 1997), thus pulling the concept of performativity away from a subject who speaks. Fundamental to this turn is the ontological assumption that reality is constituted through our language practices or our discursive constructions. Only statements deemed meaningful circulate in fields of discourse and can constitute reality. We not only know the world and our place in it by discourse but are also constituted and constrained by discourse. Thus, performativity is no longer the discrete action of a subject, but the constitution of a subject through discourses that reiterate norms (Butler, 2010).

The turn within linguistics from speech act to discourse is followed by a material turn (Callon, 1998, 2007; MacKenzie, 2006a, 2006b; Barad, 2003, 2007). It is recognised that language should not be given too much power in the formatting and construction of the world; statements can only impact the world if matter, humans and non-humans that we experience in the world, associates with it. This implies that performativity is not simply located in statements or discourse, but in the associating of the discourse with human and non-human actors (Callon, 1998, 2007) or, even more fundamentally, in entangled materialdiscursive practices (Barad, 2003, 2007). 
Saying that accounting is performative implies that accounting is somehow constitutive of a reality. In itself, this is not a particularly innovative insight. Explicit talk about the performativity of accounting is predated by the recognition that accounting is constitutive of the world in which it acts (Burchell et al., 1980; Hines, 1988; Miller and Power, 2013; Power, 2021). It is well documented that accounting constitutes governable entities, including governable persons. Such persons develop a disposition towards the requirements of accounting and internalise the categories through which they are described (Miller and O'Leary, 1987; Miller, 1992). Recently, Power (2021) theorises the micro-foundations of such disposition development in an Audit Society as resulting from a performative process. However, although Power's theorising explores the process of a collective formation of dispositions, I suggest that it does not go far enough in exploring how accounting is implicated in the further materialisation of reality; in the (re)constitution of meaningful object positions and subject positions, of meaningful positions for non-humans and for humans. It is as if performativity concerns the formation of a collective cognitive disposition, as if it is a cultural mechanism, not a material mechanism. But how does accounting come to matter, how does it construct material reality? Does it do so indirectly, mediated by dispositions in the human mind that guide humans in their decisions and actions, or more directly? Does accounting perhaps have an agency of its own? Or, if not purely of its own, does it perhaps have agency through its relations with matter in the broad sense of the word, through its relations with a heterogeneous world consisting of more or less fluid humans and non-humans? To explore these questions, we need to go beyond an understanding of accounting's performativity in forming human dispositions (something that happens in the human mind) to an understanding of accounting's performativity in forming meaningful positions for humans and non-humans (something that creates material reality).

This paper explores and develops different conceptions of accounting's performativity. More in particular, it makes two contributions. First, it produces a framework for conceptualising accounting's performativity (Table 1), and, second, it advances a particular posthumanist understanding of performative accounting.

As for the first contribution, the framework articulates different conceptions of performative accounting and substantiates each conception with extant research [1]. A number of papers were selected: Ezzamel, 2009; Dambrin and Robson, 2011; Vosselman, 2014; Revellino and Mouritsen, 2015, 2017; Mouritsen and Kreiner, 2016; Minnaar et al., 2017; Busco and Quattrone, 2018a; Baker and Modell, 2019; Boedker et al., 2020; McLaren and Appleyard, 2020; Faulconbridge and Muzio, 2021; Ruff, 2021). In addition, I selected papers published in journals in the management -and organisation (MOS) discipline (Keevers et al., 2012; Orlikowski and Scott, 2014; Van Erp et al., 2019; Power, 2021). Two of these papers in MOS journals (Orlikowski and Scott, 2014; Keevers et al., 2012) address accounting and valuation as materialdiscursive practices. So far, such papers are absent in the leading accounting journals.

The second contribution is an advancement of a Baradian posthumanist understanding of performative accounting. Such an understanding has the potential to further explore a material turn in studying the performativity of accounting. Although by at least touching upon the work of actor-network theorists such as Latour and Callon a number of studies indeed recognise that, to become performative, accounting has to associate with matter, such studies largely take boundaries between meaningful humans and non-humans as pre-given. Apart from some early examples published in MOS-journals (Keevers et al., 2012; Orlikowski and Scott, 2014) studies do not produce detailed accounts of how humans and non-humans get meaningfully positioned. Therefore, I argue for an advancement of a posthumanist (Barad, 2003, 2007) [2] understanding of accounting's performativity. This is an understanding that does not reject the existence of humans and non-humans, but that 
QRAM 19,2

acknowledges that they get meaningfully positioned out of an entanglement of humans and non-humans in their becoming. More specifically, a posthumanist account focusses on how meaningful positions for humans, non-humans and the boundaries between them are performed through practices. Accounting, then, is conceived as a boundary making and world-making practice. It is not that the practices are done in the world, that the world contains the practices. It is the other way around: practices (including accounting practices) (re)constitute the world. This insight positions accounting as an exclusionary ethicalpolitical practice that should be called to account. Such posthumanist understanding goes beyond Power's account of accounting and boundary making, as his account starts from pre-given entities (an "entity assumption") and the relations between them (Power, 2018).

In section two, I briefly discuss foundational conceptions of performativity, followed by a third section in which I produce a framework that articulates several conceptions of accounting's performativity. In section four, I argue for an advancement of the study of accounting as an exclusionary boundary making practice, a study that has the potential to discuss the ethics that are disclosed through the encounter of the practice of accounting with other practices. In section five I end up with concluding remarks.

\section{Foundational conceptions of performativity}

Performativity has been related to speech acts, to discourse, to networks of associations between humans and non-humans and to intra-actions.

\subsection{Performativity and speech acts}

Early conceptions of performativity in the organisation and management disciplines have displaced John Austin's initial insights from their language setting to expose them to new contexts (Denis, 2006; Gond et al., 2016). To Austin (1962), language is not essentially constative and not all sentences are descriptive. The uttering of a sentence can also be (a part of) doing an action: "to say something is to do something; or by saying something we are doing something" (Austin, 1962, p. 12). He distinguishes between illocutions and perlocutions. The first are speech acts that are immediately productive of realities that correspond with the intentions of the speaker, for example as when Christine Lagarde, president of the European Central Bank, announces a decrease in interest rate. Illocutions require the pre-existence of certain "felicitous conditions" (Austin, 1962); for example, Christine Lagarde a priori possesses the formal position of president and certain procedures are followed. Perlocutions are interventions that generate activities that may either bring about felicitous conditions or fail to bring them about. For example, if top management of a private company announces a big investment in new technology, such investment will only be realised if other people endeavour to make it happen and if the right circumstances are in place. Unfortunately, however, along the way there always is the risk of a breakdown and disruption that can pull the effects away from the original utterance. It is here where perlocutionary performativity is located. It is the mobilising and generative power of such breakdowns and disruptions. Callon (2010) therefore submits that an illocution may be viewed as a special case of a perlocution: a case where there are no such breakdowns or disruptions because all felicitous conditions are met. As Callon argues, illocutionary performativity is rare; in the words of Austin misfires, that is speech acts that do not realise the underlying intentions, are the rule. Such misfires spawn matters of concern (Callon, 2010). Controversies and tensions come to exist and they make the effects of the original utterance unpredictable.

Related to speech acts, Butler introduces the concept of excitability (Butler, 1997). Speech acts, she argues, are always beyond the control of the speaker. They are ex-citable. 
Excitability happens when the speech-act circulates away from its original production. There is always a possibility for resignification of the speech act, for a different conveying of its meaning, something what Butler calls the "open temporality" of the speech act.

\subsection{Performativity of discourses}

Challenging Austin, Judith Butler warns us that we should not overvalue the meaning of the subject who speaks (Butler, 2010). Although a decrease in interest rate may be brought about by a speech act of the president of the ECB, Butler would submit that a speech act is in fact a reiterated form of discourse. The president learns what to say and must speak in codified and ritualised ways. There is a discourse that precedes and that makes the speech act of a subject (in this case the president of the ECB) possible.

Drawing on French poststructuralists such as Foucault, Althusser and Derrida, Butler develops the concept of iterability. To Butler, performativity is no longer traced back to the discrete action of a subject, but to the constitution of a subject through the constant repetition of speech acts or discourses that reiterate norms (Butler, 2010). Such repetition is a sign of power, becoming performative only when "action echoes prior actions and accumulates the force of authority through the repetition of a prior, authoritative set of practices" (Butler, 1993, pp. 226-227). It is through this reiteration that one is subject and subjected within discourses and becomes a subject through performativity. Thus, to Butler, performativity is the "(re)making up" of the subjects (Butler, 2010). Performativity is not about what pre-existing subjects say and do, not about an immediate consequence of human agency, but is about the constitution of subjects. The identity of subjects is instituted through "a stylized repetition of acts" (Butler, 1988, p. 519). Humans with their particular identities are discursive formations. Power in the discourse is signified by reiteration [3].

\subsection{Performativity in heterogeneous networks}

Similar to Butler, Callon challenges Austin's centring of a speaking subject. He particularly focusses on the performativity of economics (Callon, 2007, 2010). To become a performative discourse, economics are in need of an appropriate heterogeneous network of humans and non-humans. It is through such a material turn to a network of humans and non-humans that economic theory may produce reality, that it may (re)make both subjects and objects. By concentrating on activity in these heterogeneous networks, Callon focusses on perlocutions (Callon, 2010). His "performativity thesis" claims that economics format the economy rather than describing and explaining it. The thesis is thus about the perlocutions of the theory and not about the illocutionary acts of economists. Economic theory associates with matter, with heterogeneous networks, it does not simply rule over the world from the outside. The theory or model is not outside the world to which it refers, but it requires that very world to realise itself. Conversely, the world to which it refers is meaningless without the discourse (economics) that puts it into action (Callon, 2007, p.319). The theory produces a frame that marks the cognitive boundaries within which interactions take place. It excludes and rejects. As the heterogeneous networks are always fragile, the general rule for Callon is, however, that the frame produces overflows, transgressions of the boundaries of the frame. Perlocutionary performativity implies that overflows are the rules of the game (Callon, 2010).

By not locating performativity in discourses but in the heterogeneous networks where economics plug in, Callon makes a material turn. Economics can only become performative through plugging into heterogeneous networks, socio-technical "agencements" through which both humans and non-humans carefully adjust to one another. "Agencements" are networks of relations; they are not things, but processes or doings. The "agencements" 
QRAM

19,2

locate performative agency (Gherardi, 2017). Once economic theory is plugged in, it may become performative in the sense that it for example shapes the calculative equipment and accounting devices as well as actions undertaken (Callon, 2007). In its most effective consequences, economics are performative of "Homo Economicus".

MacKenzie (2006a, 2006b) builds on Callon's performativity thesis by distinguishing four types of performativity (2006a, p. 17). First, there is generic performativity when an aspect of economics (a theory, model, concept, procedure, data set, etcetera) is used by participants in economic processes, such as regulators, investors and managers. Second, there is effective performativity when the practical use of an aspect of economics has an effect on economic processes. Third, there is Barnesian performativity (named after the sociologist of scientific knowledge Barry Barnes) when the practical use of an aspect of economics makes economic processes more like their depiction by economics. MacKenzie contrasts this strongest type of performativity with counter-performativity, that makes economic processes look less like their depiction by economics.

MacKenzie's distinction is not without challenge. Particularly Butler questions MacKenzie's lack of a discussion of Austin's perlocutionary performativity (Butler, 2010). The distinction between Barnesian performativity and counter-performativity goes back to the conceptualisation of Austin's illocutionary performativity, as both concepts are linked to the intentions laid down in a model. If the intentions are realised then there is Barnesian performativity; if, in contrast, the intentions are not realised then there is counterperformativity initiated by alternative models. Performativity is thus related to the successful realisation of the intentions; counter-performativity is related to a failure, to a misfire (or even a backfire when the model changes as a consequence of resistance); other models prove to be more powerful. The notions of perlocutionary performativity and of perlocution (Callon, 2007), however, allow for a more open-ended and dynamic view that does not relate the concept of performativity to its success. In such a view, performativity can go in different directions (D'Adderio et al., 2019); it is not destination but an ongoing journey (Garud and Gehman, 2019). Speech acts and models are relational things that may have unexpected performative consequences.

\subsection{Power-performativity}

To some, the actor-network theory (ANT)-vocabulary came as a shock (Law and Singleton, 2014), as it moved the human being away from the centre of the stage and replaced it by relations between humans and non-humans, thus treating humans and non-humans as for example accounting technologies symmetrically. To treat humans and non-humans symmetrically, however, does not imply that they both locate agency in themselves. It does not imply that intentionality is a given property of non-humans, similar to intentionality in human beings. The claim is simply that there is agency in the relations between humans and non-humans (Latour, 2005). However, the claim that there is agency in relations does not help us to understand how these actors become meaningfully positioned so that they can relate to each other in specific ways. How do human and non-human actors come to occupy meaningful positions, so that they can relate to each other? If the claim is that there is agency in the relations rather than in pre-existing meaningful actors, the question turns from "how powerful actors engage in relations" into "how powerful relations (re)create meaningful positions for humans and non-humans". If there are no pre-existing meaningful actors that relate to each other but if there are relations that (re)produce meaningful human and nonhuman actors, we need to go to a more fundamental level and ask what exactly is building the ground, is laying the foundations for the relations. How is it that relating (associating and interacting) becomes possible if there are no pre-existing meaningful actors? To answer 
this important question, we need to recognise that there is a constitutive power at work that is not located in pre-existing actors, but in a "flow of agency" (Barad, 2007) that conditions possibilities to enact and become enacted. Visser and Davies (2021) label such performativity as power-performativity, which is a term that fits with a posthumanist understanding. When we think of agency as a "flow" we recognise that it inherits conditions of possibility from prior actions and imparts conditions of possibility to subsequent actions (Deleuze and Guattari, 1987). We need to show how through a performative flow of agency actors are brought in a position to meaningfully relate to each other, to enact and to become of accounting enacted upon. Such flow of agency is located in practices that are not mobilised by human intentionality per se, practices in which self-contained rational and intentional human actors interact with non-humans, but in practices in which the a priori distinction between humans and non-humans, between the social and the material, has no relevance. Importantly, such practices do not assemble or associate actors, as in Latourian and Callonian vocabularies, but bring actors in position, locally and temporarily, through the making of fluid and temporal boundaries between meaningful subject positions and object positions. The world is done in practices.

There is no doubt that the importance of the concept of a practice is recognised by actornetwork theorists. For example, Law and Singleton (2014) explicitly claim that a move from human-centredness towards a symmetrical treatment of humans and non-humans is not enough, but that we have to more fundamentally recognise the existence of powerperformativity (or what they call ontological performativity): boundaries between meaningful positions for humans and non-humans, subjects and objects, are performed in practices in networked relations. There are patterns of relations that are embedded in and reproduced in practices (Law and Singleton, 2014). Reality is a process of continuous creation and recreation, and we are all participants in that process. As Law (2011) claims, if such continuous creation and recreation stops, then the world starts to hollow itself out.

Law and Singleton understand practices as relations that are heterogeneously material and semiotic (Law and Singleton, 2014). They are heterogeneously material as they are more-than-human; both humans and non-humans take part in it. At the same time, they are semiotic as they draw upon signs and symbols such as words and numbers. Conceptualising accounting as a material-semiotic practice enables a detailed focus on the constitutive role of accounting in organisations and society. It should be noted that the conception of a material-semiotic practice differs from Schatzki's conception of a practice (Schatzki, 2002) that was brought into the accounting discipline by Ahrens and Chapman (2007) in developing a notion of the situated functionality of accounting. A Schatzki conception of a practice, however, still tends to overlook the constitutive role of accounting (technologies or inscriptions) in producing reality (see also Nyberg, 2009 for a similar argument).

The views expressed by Law and Singleton (2013; 2014) are very close to those expressed by Barad $(2003,2007)$ in her posthumanist account of performativity. Similar to Law and Singleton (2014), Barad (2003, 2007) understands practices not as human practices. She talks of material-discursive practices. Such practices are patterns of 'relations without relata' (Barad, 2007, p. 444), relations without pre-existing meaningful actors. There are relational patterns; not patterns of association (as a verb), but entanglements in which actors are in their continuous becoming. As Barad (2007, p. xi) explains:

"To be entangled is not simply to be intertwined with another, as in the joining of separate entities, but to lack an independent, self-contained existence. Existence is not an individual affair. Individuals do not pre-exist their interactions; rather, individuals emerge through and as part of their entangled intra-relating" 
QRAM

19,2

Barad emphasises that the entanglements form apparatuses in which meaning and matter are held together. That is, "meaning should not be understood as a property of individual words or groups of words [...]. "Meaning is made possible through specific material practices" (Barad, 2007, p. 148). Thus, for discourse to exist it has to be materially expressed through artefacts, bodies, texts, figures and so on (see also Cooren et al., 2006). To Barad, discourse is not an internally cohesive set of immaterial differentiations that rules over the material world. As for matter: it does not sit still, "matter is not competing little bits of nature, or a blank slate, surface, or site passively awaiting signification" (Barad, 2003, p. 821). Where discourse is materially enacted, matter is discursively agential. Matter and discourse are thus mutually constitutive.

In entanglements, boundaries between meaningful positions for humans (subjects) and meaningful positions for non-humans (objects) are not prior, but emerge through an activity that Barad coins as intra-action (Barad, 2003, 2007). The notion of intra-action differs from that of interaction. It signifies that the activity is not between pre-given meaningful actors, but between humans (subjects) and non-humans (objects) that are "ontologically open" (Introna, 2013); between subjects and objects in their becoming. It is in the intra-action where power-performativity is located. Such performativity is a power that is consequential of the (always temporal) meaningful subject positions and object positions, of the boundaries and relations between them.

\subsection{Performativity as a search for efficiency}

The foundational conceptions of performativity as discussed above somehow are in line with Austin's (1962) work. There is, however, also an alternative conception as suggested by Lyotard (1984). His conception of performativity explicitly sidesteps the work of Austin and takes a different direction. As Cabantous $e t$ al. say, it is an "almost coincidental use of a similar term" (Cabantous et al., 2016, p. 200). To Lyotard, performativity is a concept related to a mechanism in a (societal) system that enhances the pursuit of efficiency measured according to an input/output ratio. He wants us to critically evaluate the effects of the preoccupation with efficiency in postmodern society. His ideas laid the ground for "anti-performative" Critical Management Studies (CMS), and more recently for the so-called "critical performativity" in CMS. Critical performativity involves active and subversive intervention by critical researchers into managerial discourses and practices (Spicer et al., 2009, p. 538), away from the search for efficiency. Wickert and Schaefer further develop the notion of critical performativity into the notion of "progressive performativity" as a "concept for guiding managerial behaviour in different and possibly more reflexive directions" (Wickert and Schaefer, 2015, p. 109). Cabantous et al. (2016) critically evaluate these concepts, which subsequently led to additional comments by Fleming and Banerjee (2016), Schaefer and Wickert (2016); and Spicer et al. (2016); and a reply by Learmonth et al. (2016).

\section{Conceptions of accounting's performativity: a framework}

The connecting of the concept of performativity to speech acts, discourses, heterogeneous networks and material-discursive practices [4] leads me to suggest four conceptions of accounting that may connect to performativity: accounting as an intentional act of calculation (similar to a speech-act); accounting as a discourse (as a meaning or as a frame); accounting as an actor in heterogeneous networks; and accounting as a material-discursive practice. Table 1 relates these different conceptions of accounting to a contrast between "performativity as destination" and "performativity as an ongoing journey" (Garud and Gehman, 2019) [5]. Performativity is a destination when it is placed in a context of successful realisation of underlying intentions; it is an ongoing journey when any concordance between 
accounting and "the world" "is but temporary, and is likely to be undone by a host of forces" (Garud and Gehman, 2019, p. 682).

As an act of calculation (which may include for example an investment calculation or a ranking) accounting might have effects that are intended by the calculators (Boedker $e$ al., 2020). In terms of Austin, such act of calculation is a performative illocution. A performative illocution thus has a destination. However, once uttered the calculation may also have unpredictable dynamic consequences. The act of calculation then turns into a performative perlocution that can go in every direction; it does not have a fixed destination (Revellino and Mouritsen, 2015, 2017).

As a discourse or a circulating frame accounting may become a self-fulfilling prophecy, provided that the right boundary conditions (which Austin labels as felicitous conditions) are in place (Baker and Modell, 2019; Ezzamel, 2009; Power, 2021; Ruff,2021). The accounting discourse or frame then realises the possibilities and constraints laid down in it; one might say that the discourse or general frame rules over the world. It may be expected that studies in this strand particularly examine the presence or absence of boundary conditions, thus explaining why accounting as a discourse or a frame is or is not performative. Yet, the discourse may also become an overflowing frame, thus moving away from its destination (Themsen and Skærbæk, 2018; Faulconbridge and Muzio, 2021). Whereas an accounting frame establishes a boundary for interactions, more or less independently of their surrounding context (Callon, 1998), overflows transgress the boundaries of the accounting frame. They may be counter-performative, not only in the sense that they may entail a misfire of the frame, but even in the sense that they come to backfire on the frame, so that the frame becomes less legitimate (Faulconbridge and Muzio, 2021).

As an actor, accounting is explicitly positioned as a relational thing. It associates and interacts (two-way interactions) with other actors, both of a human and a non-human nature. Accounting, then, has a relational agency that may either be more or less centrally

\begin{tabular}{|c|c|c|c|c|c|}
\hline $\begin{array}{l}\text { Conceptions of } \\
\text { accounting }\end{array}$ & $\begin{array}{l}\text { Performativity as } \\
\text { Performative } \\
\text { accounting }\end{array}$ & lestination & $\begin{array}{l}\text { Performativity } \\
\text { Performative } \\
\text { accounting }\end{array}$ & $\begin{array}{l}\text { ongoing journey } \\
\text { Examples }\end{array}$ & \\
\hline $\begin{array}{l}\text { Accounting as an } \\
\text { act of calculation }\end{array}$ & $\begin{array}{l}\text { Accounting as a } \\
\text { (counter)-performative } \\
\text { illocution }\end{array}$ & $\begin{array}{l}\text { Boedker } \text { et al. } \\
\text { (2020) }\end{array}$ & $\begin{array}{l}\text { Accounting as a } \\
\text { performative } \\
\text { perlocution }\end{array}$ & $\begin{array}{l}\text { Revellino and } \\
\text { Mouritsen (2015, } \\
\text { 2017) } \\
\text { Busco and } \\
\text { Quattrone (2018a) }\end{array}$ & \\
\hline $\begin{array}{l}\text { Accounting as a } \\
\text { discourse (or } \\
\text { general frame) }\end{array}$ & $\begin{array}{l}\text { Accounting as a } \\
\text { self-fulfilling } \\
\text { prophecy }\end{array}$ & $\begin{array}{l}\text { Ezzamel } \\
(2009) \\
\text { Baker and } \\
\text { Modell (2019) } \\
\text { Power (2021) } \\
\text { Ruff (2021) }\end{array}$ & $\begin{array}{l}\text { Accounting as an } \\
\text { overflowing frame }\end{array}$ & $\begin{array}{l}\text { Themsen and } \\
\text { Skærbæk (2018) } \\
\text { Faulconbridge and } \\
\text { Muzio (2021) }\end{array}$ & \\
\hline $\begin{array}{l}\text { Accounting as an } \\
\text { actor }\end{array}$ & $\begin{array}{l}\text { Accounting as a } \\
\text { controlled relational } \\
\text { agency }\end{array}$ & $\begin{array}{l}\text { Dambrin and } \\
\text { Robson (2011) } \\
\text { McLaren and } \\
\text { Appleyard } \\
\text { (2020) }\end{array}$ & $\begin{array}{l}\text { Accounting as a } \\
\text { mediator }\end{array}$ & $\begin{array}{l}\text { Vosselman (2014) } \\
\text { Mouritsen and } \\
\text { Kreiner (2016) } \\
\text { Minnaar et al. (2017) } \\
\text { Van Erp et al. (2019) }\end{array}$ & \\
\hline $\begin{array}{l}\text { Accounting as a } \\
\text { material-discursive } \\
\text { practice }\end{array}$ & & & $\begin{array}{l}\text { Accounting as an } \\
\text { exclusionary } \\
\text { practice }\end{array}$ & $\begin{array}{l}\text { Keevers et al. (2012) } \\
\text { Orlikowski and } \\
\text { Scott (2014) }\end{array}$ & $\begin{array}{r}\text { Table } 1 . \\
\text { Accounting and } \\
\text { performativity }\end{array}$ \\
\hline
\end{tabular}


QRAM

19,2

controlled (Dambrin and Robson, 2011; McLaren and Appleyard, 2020) or that may be a more horizontal mediator in a network of associations (Vosselman, 2014; Mouritsen and Kreiner, 2016; Minnaar et al., 2017: Van Erp et al., 2019). In the latter case, it is an ongoing journey, while in the former its relational agency has a destination. As a mediator, accounting is a performative power in a heterogeneous network. It does not have an agency of its own, but it has a relational agency as it associates with other actors.

As a material-discursive practice accounting never has a destination. It intra-acts with other organisational practices. In the intra-action there is a performative agency. Here, performativity has no authorship. It is consequential of (always temporary) meaningful subject positions and object positions, and the boundaries and the relations between them. One might say that an authorship-free "power-performativity" (Visser and Davies, 2021) continuously (re)constitutes the world.

In Table 1, the different conceptions of accounting are related to performativity as destination and performativity as ongoing journey:

\subsection{Accounting as a (counter)-performative illocution}

3.1.1 Boedker, Chong and Mouritsen. Boedker et al. (2020) examine the performativity of a ranking. The ranking they study is The Intellectual Asset Health Check for Australian governmental organisations. The management of a specific public organisation uses the device in transforming the organisation from a tangible asset company to a knowledgebased company. Boedker et al. (2020) conceptualise performativity in terms of an expected outcome, an intended destination: that of a knowledge-based company. The authors adopt MacKenzie's view that calculative models such as rankings are "engines that transform human activity rather than cameras that merely record what humans do" (Boedker et al., 2020). The engine was adopted and used by the management of the organisation as a diagnostic benchmarking device that would identify organisational performances, and enable the implementation of "intervention strategies" to lift such performances. In the view of the authors, performativity is the power of the engine to produce a lift of performances. Thus, in terms of Table 1, ranking is expected to be a performative illocution. It is a standalone act of calculation with the potential to construct the world in its image, provided that the right conditions are in place. Findings in this paper show and explain the unsuccessful one-way transport from illocution to destination. The ranking does not reach its intended destination. On the contrary, it produces effects that are "counter" or contrary to its own utterances and to the underlying human (managerial) intentions. In that sense the findings reveal a counter-performative misfire. The ranking becomes a source of protest, rather than progress. In the words of the authors: the ranking was "turned on its head, taken out of the hands of management and used against them" (Boedker et al. p. 18). The findings do not reveal, however, how the effects backfire to the ranking, that is how the ranking and its underlying intentions are impacted by the counter-performativity.

\subsection{Accounting as a performative perlocution}

3.2.1 Revellino and Mouritsen. In their study of the Italian innovation, "Telepass", Revellino and Mouritsen demonstrate how calculative practices are engines that participate in luring actors into new things by inspiring them to ask new questions and to see new opportunities (Revellino and Mouritsen, 2015). Performativity, in this study, is the degree of the power of the engine (calculative practices) to "lure people into actions whose consequences may be nearer to or further away from the promises of the engine than expected” (2015, p. 34). The study explicitly reveals how the calculative practices are not stable; while they produce innovation, the innovation also (re)produces the calculative practices. This is an ongoing 
interactive process. The calculative practices mobilise knowledges about the effects of innovation that trigger further innovation, whereas, in turn, the innovation leaves traces that can develop new calculative practices. The trajectory of innovation is thus "a string of drifts mobilised by the performativity of calculative practices' (Revellino and Mouritsen, 2015, p. 31). In line with an earlier study by Mouritsen, Hansen and Hansen (2009), the study focuses on how accounting surprisingly fuels the process of innovation. Vice versa, the process of innovation surprisingly and unexpectedly impacts and changes the accounting engine. Accounting, then, is transformed via knowledge about the effects of the innovation.

It helps to organise the world but it does not remain stable. It both mobilises and is part of the drift.

In another paper, Revellino and Mouritsen (2017) link the concept of performativity to Butler's concept of excitability. In their 2017 study of the process of Telepass innovation they conceptualise accounting as signs that are citable. It is when the act of calculation circulates away from its original production that the accounting signs produce excitability as it produces effects that go beyond the citational power of its signs. Apparently, accounting's performativity is in its excitability. The effects of the calculative act travel beyond the intentions and the control of the calculative mind and in that sense, accounting proves to be perlocutionary performative. The calculative act of accounting sets in motion a pervasive movement of innovation of Telepass, a movement that enters spaces other than originally forecasted. Chains of actions are produced, with unexpected consequences. For example: as a consequence of the investment in Telepass public goods such as safety, traffic fluidity, reduced time taken to travel from one point to another on the motorway were developed, and, conversely, it saved the motorists' time by permitting them avoiding queues and giving them freedom of movement (Revellino and Mouritsen, 2017). The calculative act proved to travel an open journey with possibilities for the resignification of the accounting signs, for the conveying of new meaning through accounting.

3.2.2 Busco and Quattrone. Accounting may have inventive capacities and generate innovation (Busco and Quattrone, 2018b). Busco and Quattrone develop the concept of accounting as a "maieutic machine" as opposed to an answer machine and illustrate this concept by presenting a case study on the development of a new fashion line (Busco and Quattrone, 2018a). The "maieutic machine" refers to "the Socratic method of generating knowledge by asking questions, and it is derived from the old Greek, 'maieuticos', midwifery" (Busco and Quattrone, 2018a, p. 2). As a maieutic machine, accounting enforces a community to ask questions with the never-fulfilled promise of a compromise. A maieutic machine is a rhetoric machine that sustains inventions through generative "in-tensions". In that sense, although the authors do not do that themselves, we can label the maieutic machine as a performative engine. It produces effects, not stable re-presentations. It is not a machine that produces mechanical and predictable movements, but it constructs thought and material. It is an inscribing machine and as such it invites to explore and interrogate that which is not visible (Busco and Quattrone, 2018a). Through inscribing, humans at the one hand reduce the organisational world to what is inscribed, but at the other hand develop the organisational world through the interventions and inventions the inscription allows for. So, as Busco and Quattrone (2018a) convincingly argue and show, the machine produces two opposing movements: reduction and augmentation. Thus, the performativity of the machine is open-ended; it can go in every direction.

\subsection{Accounting as a self-fulfilling prophecy}

3.3.1 Ezzamel. Although not focusing on the discursive formation of subjects, Ezzamel draws on Butler's $(1993,1998)$ work. He particularly focuses on reiteration: "As a 
QRAM

19,2

performative set of repetitive discursive practices, accounting rituals are productive of the effects that they name, regulate and constrain" (Ezzamel, 2009, p. 353). Ezzamel particularly explores the link between accounting and order in the New Kingdom (1552-1080 BC). He examines the discursive power of accounting in ancient Egypt as it combines with linguistic texts and pictorial scenes in architecture to produce a monumental discourse that made possible the construction and perpetuation of an orderly schema. Such schema constructed order in the cosmos, on earth and in the netherworld. One might say that it ruled over the world.

3.3.2 Baker and Modell. Baker and Modell (2019) study the performativity of novel conceptions of corporate social responsibility (CSR). Taking the position of critical realists, they insist that performative effects are always conditioned by extant realities such as those manifested in long-standing, social structures. Their empirical analysis draws attention to two pre-existing social structures that take the form of norm cycles (related to customer demands and labour rights). Their findings implicate that a novel conception of CSR may, in a specific context, become a self-fulfilling prophecy, but only when these two boundary conditions are in place. Although they are not prepared to go as far as Felin and Foss (2009) to argue that novel conceptions of CSR only become performative if they reinforce relatively immutable realities that are inherently felicitous to such novel conceptions, they do search for the situated structural boundary conditions of CSR to realise itself in situ.

3.3.3 Power. Power (2021) mobilises MacKenzie in modelling the "micro-foundations" of performance accounting (and, more generally, of the audit trail). He develops a model of how dispositions towards performance accounting may be collectively realised and how, as a consequence thereof, professional values may be replaced by other values, particularly values of the market. Drawing on MacKenzie, the model distinguishes three stages. In the first stage, there is generic performativity: performance accounting is performative only in a weak sense. Actors simply adopt new performance accounting because of institutional pressure (compliant adoption) but also resist it. In a second stage, the performance accounting becomes effectively performative through repetition and routinisation of performance accounting; the resistance becomes weaker as actors do not have much choice than to meet the requirements. A third stage is characterised by amplification as organisational actors internalise the requirements from performance accounting. There is performativity in a Barnesian sense: performance accounts come to be understood as representing an organisational truth.

Essentially, Power's model explains a self-fulfilling prophecy. Performativity is located in the repetition, routinisation and internalisation of performance accounting. However, the conceptualisation of performativity as a mechanism in a self-fulfilling prophecy does not go far enough in showing how performance accounting is implicated in the further production of reality. It explains success or failure in terms of beliefs only. Callon would probably disagree that this is about performativity, as he claims (Callon, 2007, p. 17): "Whereas the notion of a self-fulfilling prophecy explains success or failure in terms of beliefs only, that of performativity goes beyond human minds and deploys all the materialities comprising the socio-technical agencements that constitute the world in which these agents are plunged: performativity leaves open the possibility of events that might refute, or even happen independently of, what humans believe or think" (Callon, 2007, p. 17).

3.3.4 Ruff. In her study of the performativity of impact devices for the assessment of the social impact of an organisation (logical frameworks, balanced scorecards and Social Return on Investment Impact Maps), Ruff (2021) demonstrates how such devices are not neutral and disinterested technologies but how their physical-visual form performatively enacts hardwired biases into impact assessments. While Ruff notes there may be ongoing 
performative effects (performativity as an ongoing journey) she only investigates the initial performativity as destination. The devices are hardwired with particular discourses about what is reasonable and sayable. Thus, although the performativity of such devices may not entail a full self-fulfilling prophecy, it would be wrong to think that when a device is applied faithfully it creates a more accurate measure of impact. This would ignore the meaning that is embedded in the device itself. As Ruff claims, one implication of this is that impact measurement is better served with a plurality of devices.

\subsection{Accounting as an overflowing frame}

3.4.1 Themsen and Skcrbck. Themsen and Skærbæk (2018) examine the long-term dynamics among a best-practice risk management framework. They show that the discourse-as-frame, i.e. the Project Management Institute's Body of Knowledge (PMBOK), establishes the boundaries of the forms of uncertainties that are accepted and included as risks. They term the accepted and included risks 'pure risks and the risks excluded after disagreement impure risks. They then show that the construction of impure risks challenges the predictions of the framework causing a false sense of security for the project objectives, and that the continuous readjustment of technologies is necessary to ensure the long-term realisation of these predictions.

To demonstrate the performativity of PMBOK the authors mobilise Callon's intertwined concepts of framing and overflowing (Callon, 1998). The performativity of PMBOK is particularly in the overflowing. Risk consultants contained, albeit only temporarily, the recurrent stream of overflows that emerged. That required costly investments through which they managed to temporarily re-actualise the predictions of the PMBOK. This prevented PMBOK from misfires.

3.4.2 Faulconbridge and Muzio. Referring to D'Adderio et al. (2019), Faulconbridge and Muzio (2021) conceive of the performativity of a discourse-as-frame (a generic calculative device) as a non-linear dynamic process. The generic calculative device they study is the PEP; the "Profits per Equity Partner" used in the English legal profession. Essentially, the paper theorises a dynamic 'legitimacy-performativity nexus' from the empirical setting. By linking the concept of performativity to that of legitimacy, the authors do not locate the origins of performativity in the intentions laid down in the device by its designers, but in the desirability and appropriateness of the calculative device in a socially constructed system of norms, values, beliefs and definitions. The authors argue and demonstrate that as the legitimacy of the device develops, its performativity gets stronger but ultimately turns into a counter-performativity of the device in the sense that its legitimacy is undermined. Many PEP-oriented strategies and practices become counterproductive and problematic. Counterperformativity, then, is not simply a misfire, but a backfire as it negatively impacts the legitimacy of PEP. The authors conclude that there is a paradox at play: "the increasing legitimacy of PEP produces and is initially sustained by its performativity, but eventually Barnesian performativity triggers counter-performativity which in turn undermines its legitimacy" (Faulconbridge and Muzio, 2021, p. 14).

\subsection{Accounting as a controlled relational agency}

3.5.1 Mclaren and Appleyard. Similar to Boedker et al. (2020), McLaren and Appleyard (2020) study the performativity of a ranking. However, they do not conceive of a ranking as an act of calculation, but as an actor. They study the performativity of the BBFAW: the Business Benchmark on Farm Animal Welfare. Such performativity is, in their wordings, the "potential for BBFAW to become the measure of FAW" (p. 51). As the authors state, "full performativity (of the BBFAW) would come into play if internal accounting systems were changed so that 
QRAM

19,2

BBFAW becomes part of the information set used for decision making (including for resource allocation) and/or if it changes behaviour and practices surrounding Farm Animal Welfare for the firms and their suppliers" (McLaren and Appleyard, 2020, p. 38).

The authors specifically focus on what they call the "characteristics" for such performativity to occur. To say it in Austinian words: what are the felicitous conditions? One of these conditions is the coming into being of adequate networks. Policy makers should be aware of the importance of proper network building between ranking creators, stakeholders such as investors, customers and suppliers and scientific actors. Thus, although in the eyes of the authors performativity is a destination, they also define it in process terms as relational and dynamic. To reach its destination, the network of relations has to be conditioned and guided. It has to be orchestrated by the creators of the ranking. There is a destination, but arrival is conditional upon the network around the BBFAW with which actors associate. Along the way, the furniture of the ranking might (have to) change.

3.5.2 Dambrin and Robson. Rooted in early work by Robson (1991, 1992), Dambrin and Robson study the performativity in "flawed" accounting inscriptions (Dambrin and Robson, 2011). An inscription is a material textual translation of any setting, such as written texts, tables and charts, numbers, lists and so on, that is to be acted upon (Latour, 1987; Qu and Cooper, 2011). As Latour $(1987,1999)$ puts it, inscriptions are the forms of an object (in this case a performing drug representative) that can travel. Accounting technologies have the ability to inscribe, thus enabling a calculative centre as for example headquarters to exercise control from a distance. The interesting thing in Dambrin and Robson's study is that the inscriptions are flawed, as the chain of translations from matter (sales of drugs by drug representatives to medical doctors) to form (inscriptions) is not reversible; doctors' prescriptions of medicines that generate sales to the pharmaceutical company remain hidden for headquarters, due to societal regulations. There are thus interruptions in controlling the performances of drug reps from a distance. Nevertheless, the imperfect inscriptions succeed in being performative, because, as Dambrin and Robson (2011) demonstrate, they succeed in producing and maintaining commitment from the drug representatives to the pharmaceutical company, and in controlling the performance of the drug representatives from a distance. Apparently, the flawed inscriptions reach their destination: control from a distance. Such control is, however, never rendered unproblematic; the use of accounting inscriptions as a medium of control does not guarantee that the controller can predict the outcomes of the process with certainty (see also Lowe, 2001). Dambrin and Robson (2011) provide contextual explanations for the performativity of the flawed inscriptions.

\subsection{Accounting as a mediator}

3.6.1 Mouritsen and Kreiner. Mouritsen and Kreiner talk about the performativity of accounting as a mechanism that "makes the world" (Mouritsen and Kreiner, 2016) in unexpected ways. They relate such mechanism to the progress of a decision, which they see as a promise. The realisation of the decision, which happens over a temporal order, may be challenged through various trails in which accounting participates and such challenges may lead to additional investments. Thus, decision makers have to forgive and forget. In terms of Table 1 , the decision is a performative perlocution, and accounting is an actor that mediates in such performativity. As a consequence, there are unexpected real consequences of the decision.

3.6.2 Vosselman. Several accounting studies give evidence that accounting mediates in bringing and keeping economics into life. In the extreme form, the performativity of economics is the generative capacity of economics to frame "Homo Economicus" and to 
equip it with "prostheses which help him in his calculations and which are, for the most part, produced by economics" (Callon, 1998, p. 51). It is not the economists, not the humans, who produce Homo Economicus, but the dynamics in the heterogeneous assemblages. Thus, the performativity of economics is a relational enactment. Accounting proves to mediate in the performation of economics in socio-technical "agencements". Vosselman (2014) reviews studies that convincingly demonstrate how accounting, to different degrees, is performative in bringing economics into life (Christensen and Skærbæk, 2007; Roberts and Jones, 2009; Vollmer, Mennicken and Preda, 2009; Skærbæk and Tryggestad, 2010; Cushen, 2013). More recently, Warren and Seal demonstrate how the Discounted Cash Flow model frames negotiations between actors around narratives of economisation, marketisation and financialisation in a regulated industry of electricity generation (Warren and Seal, 2018).

3.6.3 Van Erp, Roozen and Vosselman. Whilst Faulconbridge and Muzio (2021) relate performativity to legitimacy, Van Erp et al. (2019) relate performativity to functionality. In contrast with functionality, they do not conceive of performativity as a destination, but as a journey that may end up in unexpected places. They focus on the performativity of a management accounting and control system (MAC) as it is designed in a health-care organisation comprising nursing homes and homes for the elderly. MAC is purposefully designed by the department of Finance and Control and is intended to be functional for decision support and control purposes. In the study, performativity is explicitly not about how the design is (un)successful in realising its intended functionalities. The authors emphasise that performativity can go in every direction. Thus, we may conclude that the study examines a journey of a design as a performative perlocution; a journey with unpredictable destinations. The original design is reconceptualised as an actor. The performative process is in MAC's actor-network; it is a relational enactment with diverse outcomes that are always temporal. The MAC-design proves to have unexpected dynamic consequences, that also backfire to the MAC-design. Gradually, MAC becomes an "object multiple" (Mol, 2002) in network space; there is more than one MAC.

Although the study distinguishes functionality from performativity, it also demonstrates that functionality and performativity are not strictly separated. The authors observe that the performativity of accounting is in the purposive attempt to represent and intervene from time - and space distances.

3.6.4 Minnaar, Vosselman, van Veen-Dirks and Zaheer-ul-Hassan. Minnaar et al. (2017) study the performativity of a contract and the incorporated control structures in an interfirm relationship. In their study, performativity is not a destination. It is not the realisation of the clauses in the contract nor of the intentions behind the contract. The contract's performativity leads to unexpected places. The contract performed in unexpected ways. Although it did not in any way guide the day-to-day activities of the parties involved, its mere existence forced the parties to make the relationship work and to enter into a re-contracting process. A re-contracting process yielded a new contract, which created the basis for a heterogeneous network to which properties of trust were assigned and in which the relationship developed. Performativity was an ongoing journey.

\subsection{Accounting as an exclusionary practice}

While in disciplines such as philosophy and MOS performativity has already been located in exclusionary practices, thus providing a posthumanist Baradian understanding, the accounting discipline has largely been silent. To exemplify the significance of such understanding, in what follows, I draw on two papers published in MOS-journals, i.e. Keevers et al. (2012) and Orlikowski and Scott (2014).
Performativity 
QRAM 19,2

3.7.1 Keevers, Treleaven, Sykes and Darcy. As an early example of a Baradian view of performance measurement, Keevers et al. perform a micro-study into the performative consequences of the introduction of a new performance measurement apparatus labelled as "Results Based Accountability" (RBA) in an organisation for youth care (Keevers et al, 2012). The workers in the organisation do not experience the RBA-practice as a practice from a space distance and a time distance; rather, it becomes a practice within the practice of youth care. As Keevers et al. (2012) show, the emergence and becoming of RBA in the apparatus of care and the reconstitution of meaningful positions for objects (computers, software) and subjects (youth workers, youngsters, supervisors) and new legitimate ways of working that are consequential of it, is not without tensions. In Southern Youth, a locally based community organisation that provides a comprehensive and integrated range of accommodation, support and advocacy services to homeless and vulnerable young people and their families, RBA comes to intra-act with the care practices. Although the authors of the RBA program, Friedman and Handley (2008), strongly advise to separate accountability and performance measurement as it is included in RBA from the service provision, and thus conceive of RBA as an apparatus of performance management that is separate from the service delivery to young people and their families, RBA definitely does not stay at a time-space distance from the practice of youth care. It becomes an apparatus that reconfigures what is included and excluded from mattering in the care practices. The new computerised case-management and outcomes-based accountability system that came with RBA and that acted as an "electronic eye" reconfigured subject and object positions that were deemed meaningful, and changed the legitimate ways of working. The "ever present" (through the computer screen) funding body inscribed new ways of working in the practice of youth care. The electronic eye became a part of the entanglement or apparatus that produced youth care. It had significant impact on the daily care practices. It caused tensions but was hard if not impossible to resist. In particular, it reduced the time available to create a "sense of belonging" and to develop young people's skills as a basis for sustaining their life changes. Such sustainability was not captured by the "electronic eye", as it would not become evident for years to come.

3.7.2 Orlikowski and Scott. Orlikowski and Scott (2014) show how valuation can be sociomaterially enacted in different ways and how different sociomaterialisations produce different accountings. They contrast two apparatuses against each other: a formulaic valuation apparatus and an algorithmic valuation apparatus. The first produces a star rating of hotels communicated through the AA Hotel Guide. It is initiated and carried by the Automobile Association (AA) and includes formal standards, objectified criteria and trained expertise while, among others, they exclude consumer opinion on hotel performance. The second is an internet-based social media platform that produces a Popularity Index of hotels, not a rating communicated through a hotel reference guide. It is initiated and carried by TripAdvisor and executes step-by-step procedures to solve specific problems set by software designers. Practices in these apparatuses include "open-ended consumer opinion, content aggregation, flexible parameters and reprogrammable criteria while excluding professional classifications and formal measures" (Orlikowski and Scott, 2014, p. 887). As a material-discursive practice (an apparatus), valuation does not simply meet a separate reality that is passively awaiting signification. There are no strict boundaries between organisational performance and the valuation of such performance; performance and its valuation are entangled. Orlikowski and Scott (2014) explore how the two apparatuses of valuation enact significantly different realities. They produce different meaningful positions for hotels, hoteliers, travellers and artefacts. The AA-apparatus produces hoteliers who are oriented to meeting and possibly exceeding the AA standards for hotel excellence, and it produces quiescent hotel guests who know about appropriate behaviour in the differently 
rated hotels. On the other hand, TripAdvisor's valuation apparatus produces attentive hoteliers who feel that they are under continuous surveillance and who have a very shortterm focus on delivering service to customers, and on continuous service innovation. In the eyes of hoteliers, quests become potential reviewers. Guests get a central position and professional experts are excluded. Ultimately, the two apparatuses of valuation produce different phenomena of travel. That is, they are differently performative. The practices mark out certain inclusions and exclusions.

\section{Advancing a posthumanist understanding of the performativity of accounting}

A posthumanist Baradian approach to the performativity of accounting focuses on the question of how meaningful entities (both human and non-human), and the boundaries and relations between them, come to exist through intra-activity in an entanglement of accounting practices with other organisational practices. It is the coming into existence (and, perhaps even more important) the exclusion from coming into existence, that is to be explored. This is not an exploration of the (social) construction of an accounting system as this would imply a pre-given distinction between humans (interpreters, designers) and non-humans (accounting systems). It is also not an exploration of the constitutive mechanism in the associating between humans, accounting as a non-human actor and other non-human actors as this is also suggestive of a pre-existing binary between humans and non-humans [6]. It is an exploration of the intra-active mechanisms between accounting practices and other practices, mechanisms through which meaningful positions for humans and non-humans and the boundaries and relations between them are locally and temporarily disclosed. Such an exploration of intra-active mechanisms is an exploration of power-performativity (Visser and Davies, 2021) or ontological performativity [7]. It not only reveals what comes to matter (in both senses of the word) but also (and most importantly) what does not come to matter. It reveals what remains silent; what remains excluded from mattering. In short: a posthumanist exploration reveals how accounting is an exclusionary boundary making practice.

Power-performativity is without authorship. It is connected to an agency that is not located in human beings but in intra-actions. It is important to note that this does not mean that the existence of humans is rejected. Humans do exist and they are definitely not freed from responsibility and accountability. It is just that they do not precede intra-actions as meaningful self-contained entities, but that they come meaningfully into being within the intra-actions. They are implicated in the intra-actions as entangled entities in their becoming; or, as Introna (2013) says, as "ontologically open" entities. They are for example entangled parts of accounting practices through which policies, methods, technologies and infrastructures are developed. The entangled elements of the accounting practice (that form an "accounting apparatus") materialise the accounting practice, where matter is both of a human and non-human nature. They constitute the conditions of possibilities for the accounting practice to become performative. It is through intra-actions with other practices, for example hospitality practices or practices of youth care, that accounting as a practice actually becomes performative; that it becomes an exclusionary boundary-making practice. Such performativity locally and temporarily results in meaningful positions for humans and non-humans and the boundaries and relations between them. Thus, humans are both within and a consequence of performative intra-actions.

As an exclusionary boundary making practice accounting is not innocent. There is an "ethics of mattering" [8] (Barad, 2007, p. 36) in the practice of accounting as it materialises the world in a particular meaningful way, thereby excluding alternative materialisations. Accountants and managers therefore have to be accountable for the ontological existence of 
QRAM

19,2

the accounting apparatus, for its commitments and its performative effects (Mauthner, 2019, for a similar argument concerning scientific practices). The accountability for its ontological existence and its performative consequences includes an accountability for the exclusions or the "silences" (Vollmer, 2019) that the accounting apparatus produces. Posthumanist studies may particularly give voice to such silences and point to exclusions, thus insisting that accounting indeed is an ethical-political practice. They have the potential to position a positive view of an accounting practice as an ethical concern. This is important, because accounting practices that, to paraphrase Haraway (1988, p. 581), "claim the power to see and not be seen, to represent while escaping representation" constitute irresponsible and unethical knowledge-making. From a posthumanist perspective, ethics is in the accounting practice, it inheres in the very practices of accounting, and not simply in codified norms and rules of ethical human conduct. Thus, posthumanist studies may disclose (rather than simply criticise) the non-innocent nature of accounting.

A posthumanist research approach to performativity puts accounting on its head. While from a humanist and representationalist perspective humans call other humans to account on the basis of accounting information, from a posthumanist perspective the more-thanhuman practices of accounting (in the broadest sense of the word, so including valuation, performance measurement, ranking) are called to account. Posthumanism does not simply reject the representationalist aim of the practice of accounting, but it does not simply accept the silence (Vollmer, 2019) that comes with it. A posthumanist account is not simply a philosophical critique or deconstruction of a representationalist stance of accounting. Research should reveal how in the entanglement of the accounting practice with other practices, things are excluded from mattering (in both senses of the word), as for example in the youth care when it entangles with results-based accountability. It should show how such exclusion is not simply radical separation, but is in processes of 'non-binary differencing' as Barad calls it (Barad, 2014). The result-based accountability in Keevers et al.'s (2012) study does not simply separate performing youth care workers (individuals who aim for good performances on the basis of performance indicators) from youth care workers who are committed to the welfare of youngsters. Performative intra-action does not entail the creation of strict boundaries between "performing professionals" and "committed professionals", but entails diffraction. Diffraction is what is formed in the day-to-day intraaction between the accounting practice and other organisational practices. In an entanglement of Result-Based Accountability practices and practices of youth care, committed youth workers are not only attentive to the youngsters with which they communicate, but also to the RBA-practice that comes to them through the hardware and software. That is, in the flow of the practice of youth work they are attentive to the RBApractice which they plug into their youth work practice. As a consequence of the entanglement there are performative moments in which the positioning of subjects (youth workers, youngsters) and objects (computers, software) and ways of working situationally and temporary come to differ from what they were. This, however, is not without ethical consequences for which not only the youth workers but also others (managers) bear responsibility and should be held accountable.

\subsection{Implications for research strategy}

An advancement of a posthumanist understanding of accounting's performativity has a number of important implications for research strategy. First, research should focus on accounting, not as a mere practice of human cognition, but as a material-discursive practice. It should focus on how accounting is materially enacted. As Orlikowski and Scott in their investigation of two prominent hotel valuation schemes currently at work in the hospitality 
industry show, "it makes a difference to valuation processes and outcomes whether valuations are produced through the trained bodies of professional inspectors annually examining the quality of the bed linen and assessing it against an explicit standard inscribed in a spreadsheet or whether valuations are produced by algorithmic aggregation of travellers' ongoing and anonymous online descriptions of personal encounters with rude service and noisy corridors" (Orlikowski and Scott, 2014, p. 888). Second, research should show how accounting is organised in an apparatus. An apparatus is not subordinate to human beings, it is not a tool that supports human cognition, but it is an entanglement of human bodies, texts, policies, instruments and technologies "in their becoming", an entanglement that conditions the practice of accounting. The apparatus of accounting materially enacts the practice of accounting. As an example, in the hotel industry the measurement of hotel performance is done through trained humans who are both enabled and constrained by a performance measurement discourse, while at the same time the humans entangle with non-humans such as hardware, algorithms and software. It is through such associations that the material-discursive practice of accounting takes shape. Third, research should reveal how the accounting apparatus is performatively intra-acting with other practices, as for example youth care or hotel gastronomy. Such performative intra-acting both includes and excludes, as is for example shown by Keevers et al. (2012) in their study of the performative effects of the intra-actions between an apparatus of resultsbased performance measurement and an apparatus of health care. Fourth, and most importantly, research could address the ethics that are disclosed by the performative intraactions, by the exclusions and inclusions produced. Studying the ethics of mattering in qualitative accounting research encompasses an understanding of the genealogy of the accounting apparatus, its situated ontological specificity and its performative consequences. Essentially, by discussing the ethics of mattering research positions accounting as an object of ethical concern.

\section{Concluding remarks}

As a first contribution, the framework summarised in Table 1 articulates that performative accounting can be (and has been) understood in different ways: as an intended destination of an act of calculation (Boedker et al., 2020); as a journey of an act of calculation, a journey without destination (Busco and Quattrone, 2018a; Revellino and Mouritsen, 2015, 2017); as a self-fulfilling prophecy mechanism inherent in a discourse or frame (Ruff, 2021; Ezzamel, 2009; Baker and Modell, 2019; Power, 2021); as an overflowing frame (Themsen and Skærbæk, 2018; Faulconbridge and Muzio, 2021); as a controlled relational agency of actors as for example a ranking (McLaren and Appleyard, 2020) or inscriptions (Dambrin and Robson, 2011); as a mediator (Vosselman, 2014; Mouritsen and Kreiner, 2016; Minnaar et al., 2017; Van Erp et al., 2019); and as an exclusionary practice (Keevers et al., 2012; Orlikowski and Scott, 2014). Each of these conceptions has merit and deserves to be further substantiated. Hopefully the produced framework can be of use for future studies.

As a second contribution, the paper advances a posthumanist understanding of accounting and performativity. I surely would not want to claim that a posthumanist concept of performativity produces better insights than others. I also acknowledge that an advancement of a posthumanist understanding is not without critique. Modell (2020) and Baker and Modell (2019), taking a critical realist stance, are strongly in favour of a structuralist understanding of performativity; an understanding that acknowledges the importance of its embeddedness in pre-existing, social structures. To them, it is the search for structural boundary conditions that sustain and constrain accounting's performativity 
QRAM 19,2

and that should be the focus of study. Apparently, they prefer to see performativity as a destination rather than an ongoing journey.

However, I have argued that a posthumanist study of power-performativity can make a distinctive contribution, particularly by positioning accounting as an exclusionary practice bringing ethical concerns to the fore. Such study gives voice to the silences and exclusions that accounting practices produce, thus potentially contributing to the production of "antidotes against the idea that any account, any slice of information, or any amount of "big data', could speak for itself - or that it should" (Vollmer, 2019, p. 15). Posthumanist field work does not aim to study the boundary conditions for accounting's performativity, nor does it aim to study how there is performativity in networks of association of which accounting is a part. Its distinctive contribution lies in giving voice to silences and in disclosing the ethics in the performative intra-actions between accounting practices and other organisational practices.

Essentially, posthumanism implies a radical change in the referent of accounting. Instead of taking a pre-given reality, pre-given subjects and objects with fixed properties as the referent(s) of accounting, accounting's referents are entanglements of subjects and objects in their becoming. Accounting, then, is not simply a world-knowing practice, but (paraphrasing Haraway, 1997) a 'world-making practice' for which its participants should be called to account.

\section{Notes}

1. My aim was not to present an exhaustive overview of all the papers that somehow mobilize foundational concepts of performativity in accounting research. Rather, my aim was to substantiate the framework that articulates conceptions of accounting's performativity with telling accounting studies. I particularly searched in the following journals: Accounting, Organizations and Society; Accounting, Auditing and Accountability Journal; Accounting and Business Research; Critical Perspectives on Accounting; Management Accounting Research; Qualitative Research in Accounting and Management. In addition, particularly because in the accounting journals I could not find papers that substantiated accounting's performativity as a material-discursive practice, I selected such papers from MOS-journals, i.e. Organization Science, Organization Studies and Scandinavian Journal of Management.

2. Posthumanism has been variously defined and understood. Mauthner (2019) points to the following three conceptions of posthumanism: transhumanism (that focuses on human enhancement through biological and technological means); non-humanism (that is concerned with the role and agency of nonhuman entities such as animals and technologies); and antihumanism (that rejects the humanist subject defined as the locus of will, reason, intentionality and consciousness). Barad's distinctive notion of posthumanism does not reject, but decentres the human subject. Essentially, Barad's notion of posthumanism questions the presumed meaningful existence and pre-givenness of all beings, including the human.

3. In their study into a CSR business case, Grisard et al. (2020) add to the notion of performative agency developed by Butler by exploring the capacity of individuals, even as they are disciplined through discourse, to bring about change. The study "shows that the subject can incrementally act to transform the dominant financial discourse governing her subjection to better align it with her desires" (2020, p. 1). This creates a space for alternative possibilities of subjection. Thus, Grisard et al. (2020) add to Butler by showing the possibility of a human agency emerging from the disciplinary process of subjection.

4. Being related to a societal system rather than to signs such as words or numbers it is hard to specifically connect the Lyotardian concept of performativity to accounting. I therefore do not include it in the development of a framework. So far, there is not much scholarly work in the 
discipline of accounting that has drawn upon Lyotard's notion of performativity, with Cooper (1997), Matilal and Adhikari, 2020 and Savage (1995) as notable exceptions. Apart from Baker and Modell who touch upon the concept of critical performativity in their discussion section (Baker and Modell, 2019), to my knowledge the concepts of notions of critical and progressive performativity were not mobilised in accounting studies.

5. Garud and Gehman (2019) articulate this contrast in a response to Marti and Gond (2018), who articulate a self-fulfilling prophecy view of performativity, thus seeing performativity as a destination.

6. In this respect, I agree with Introna (2013) that there is some irony at play in Latour's distinction between the human and the non-human, as Latour clearly aims to leave the related distinction between "culture" and "nature" behind as a "castle now in ruins" (Latour, 2005, p. 76).

7. In this sense, a Baradian posthumanist understanding of performativity bears similarities with the insights expressed by Law and Singleton (2014).

8. An "ethics of mattering" differs from an ethics of accountability that Messner (2009) mobilizes in exploring the limits of accountability. It also differs from an ethics of intelligent accountability that Roberts (2009) develops in exploring the limits of transparency. To Messner and Roberts, ethics is about responsible actions in relation to human experiences of the world; they provide humanist views of ethics, views of the problem of how the general interest and the particular interests relate to each other in the course of human interaction. An "ethics of mattering" corresponds with a posthumanist account of a world that is disclosed through performative intraactions of which we are a part. The ethical call is embodied in the mattering of the world. As Barad says: "Ethics is about mattering, about taking account of the entangled materializations of which, we are a part, including new configurations, new subjectivities, new possibilities" (Barad, 2007, p. 384).

\section{References}

Ahrens, T. and Chapman, C.S. (2007), "Management accounting as practice", Accounting, Organizations and Society, Vol. 32 Nos 1/2, pp. 1-27.

Austin, J.L. (1962), How to Do Things with Words, Oxford University Press, Oxford.

Baker, M. and Modell, S. (2019), "Rethinking performativity. A critical realist analysis of accounting for corporate social responsibility", Accounting, Auditing and Accountability Journal, Vol. 32 No. 4, pp. 930-956.

Barad, K. (2003), "Posthumanist performativity: toward an understanding of how matter comes to matter", Signs: Journal of Women in Culture and Society, Vol. 28 No. 3, pp. 801-831.

Barad, K. (2007), Meeting the Universe Halfway: Quantum Physics and the Entanglement of Matter and Meaning, Duke University Press, Durham, NC.

Barad, K. (2014), "Diffracting diffraction: cutting together-apart", Parallax, Vol. 20 No No. 3, pp. 168-187.

Boedker, C., Chong, K.-M. and Mouritsen, J. (2020), “The counter-performativity of calculative practices: mobilising rankings of intellectual capital", Critical Perspectives on Accounting, Vol.72, available at: doi.org/10.1016/j.cpa.2019.102100.

Burchell, S., Clubb, C., Hopwood, A., Hughes, J. and Nahapiet, J. (1980), "The roles of accounting in organizations and society", Accounting, Organizations and Society, Vol. 5 No. 1, pp. 5-27.

Busco, C. and Quattrone, P. (2018a), "In search of the 'perfect one': how accounting as a maieutic machine sustains inventions through generative 'in-tensions", Management Accounting Research, Vol. 39 No. 1, pp. 1-16.

Busco, C. and Quattrone, P. (2018b), "Performing business and social innovation through accounting inscriptions: an introduction", Accounting, Organizations and Society, Vol. 67 No. 1, pp. 15-19. 
QRAM 19,2

Butler, J. (1988), "Performative acts and gender constitution: an essay in phenomenology and feminist theory", Theatre Journal, Vol. 40 No. 4, pp. 519-531.

Butler, J. (1993), Bodies That Matter: On the Discursive Limits of Sex, Routledge, London.

Butler, J. (1997), "Excitable speech”, A Politics of the Performative, Routledge, New York, NY.

Butler, J. (2010), “Performative agency”, Journal of Cultural Economy, Vol. 3 No. 2, pp. 147-161.

Cabantous, L., Gond, J.-P., Harding, N. and Learmonth, M. (2016), “Critical essay: reconsidering critical performativity", Human Relations, Vol. 69 No. 2, pp. 197-213.

Callon, M. (1998), The Laws of the Markets, Blackwell, Oxford.

Callon, M. (2007), "What does it mean to say that economics is performative?", in MacKenzie, D., Muniesa, F. and Siu, L. (Eds), Do Economists Make Markets? On the Performativity of Economics, Princeton University Press, Princeton.

Callon, M. (2010), "Performativity, misfires and politics", Journal of Cultural Economy, Vol. 3 No. 2, pp. 163-169.

Christensen, M. and Skærbæk, P. (2007), "Framing and overflow of public sector accountability innovations - a comparative study of reporting practices", Accounting, Auditing and Accountability Journal, Vol. 20 No. 1, pp. 101-132.

Cooper, C. (1997), "Against postmodernism: class oriented questions for critical accounting", Critical Perspectives on Accounting, Vol. 8 Nos 1/2, pp. 15-41.

Cooren, F., Taylor, J. and Van Every. E. (Eds) (2006), Communicating as Organizing: Empirical and Theoretical Explorations in the Dynamic of Text and Conversation, Lawrence Erlbaum, Mahway, NJ.

Cushen, J. (2013), "Financialization in the workplace: hegemonic narratives, performative interventions and the angry knowledge worker", Accounting, Organizations and Society, Vol. 38 No. 4, pp. 314-331.

D’Adderio, L., Glaser, V. and Pollock, N. (2019), "Performing theories, transforming organizations: a reply to Marti and Gond", Academy of Management Review, Vol. 44 No. 3, pp. 676-679.

Dambrin, C. and Robson, K. (2011), "Tracing performance in the pharmaceutical industry: ambivalence, opacity and the performativity of flawed measures", Accounting, Organizations and Society, Vol. 36 No. 7, pp. 428-455.

Deleuze, G. and Guattari, F. (1987), A Thousand Plateaus: Capitalism and Schizophrenia, University of MN Press, Minneapolis.

Denis, J. (2006), "Preface: les nouveaux visages de la performativité, Études de Communication, Vol. 29 No. 29, pp. 8-24.

Derrida, J. (1979), “Signature event contex”, Glyph, Vol. 1, pp. 172-197.

Ezzamel, M. (2009), "Order and accounting as a performative ritual: evidence from ancient Egypt", Accounting, Organizations and Society, Vol. 34 Nos 3/4, pp. 348-380.

Faulconbridge, J.R. and Muzio, D. (2021), "Valuation devices and the dynamic legitimacyperformativity nexus: the case of PEP in the English legal profession", Accounting, Organizations and Society, Vol. 91, available at: https://doi.org/10.1016/j.aos.2020.101224

Felin, T. and Foss, N.J. (2009), "Social reality, the boundaries of self-fulfilling prophecy, and economics", Organization Science, Vol. 20 No. 3, pp. 654-668.

Fleming, P. and Banerjee, S.B. (2016), "When performativity fails: implications for critical management studies", Human Relations, Vol. 69 No. 2, pp. 257-276.

Friedman, M. and Handley, S. (2008), Neighbourhood Centres and Results Accountability: A Conversation with Mark Friedman, Local Community Services Association, Sydney.

Garud, R. and Gehman, J. (2019), "Performativity: not a destination but an ongoing journey", Academy of Management Review, Vol. 44 No. 3, pp. 679-684. 
Gherardi, S. (2017), "To start practice theorizing anew: the contribution of the concepts of agencement and formativeness", Organization, Vol. 23 No. 5, pp. 680-698.

Gond, J.-P., Cabantous, L., Harding, N. and Learmonth, M. (2016), "What do we mean by performativity in organizational and management theory? The uses and abuses of performativity", International Journal of Management Reviews, Vol. 18 No. 4, pp. 440-463.

Grisard, C., Annisette, M. and Graham, C. (2020), "Performative agency and incremental change in a CSR context", Accounting, Organizations and Society, Vol. 82.

Haraway, D. (1988), "Situated knowledges”, Feminist Studies, Vol. 14 No. 3, pp. 575-599.

Haraway, D. (1997), Modest_Winess@Second_Millenium.FemaleMan ${ }^{C} \_$Meets_OncoMouse ${ }^{T M}$, Routledge, New York, NY.

Hines, R.D. (1988), "Financial accounting: in communicating reality, we construct reality", Accounting, Organizations and Society, Vol. 13 No. 3, pp. 251-261.

Introna, L.D. (2013), "Epilogue: performativity and the becoming of sociomaterial assemblages", Materiality and Space: Organizations, Artefacts and Practices, Springer, New York, NY, pp. 330-342.

Keevers, L., Treleaven, L., Sykes, C. and Darcy, M. (2012), "Made to measure: taming practices with results-based accountability", Organization Studies, Vol. 33 No. 1, pp. 97-120.

Latour, B. (1987), Science in Action: How to Follow Scientists and Engineers through Society, Harvard University Press, Cambridge MA.

Latour, B. (1999), “Circulating Reference: Sampling the Soil in the Amazon Forest", Ch. 2 in Pandora"s Hope: Essays on the Reality of Science Studies, Harvard University Press, Cambridge, MA.

Latour, B. (2005), Reassembling the Social: An Introduction to Actor-Network Theory, Oxford University Press, Oxford.

Law, J. (2011), "What's wrong with a one world world?", available at: www.heterogeneities.net/ publications/Law2011WhatsWrongWithAOneWorldWorld.pdf

Law, J. and Singleton, V. (2014), “ANT, multiplicity and policy”, Critical Policy Studies, Vol. 8 No. 4, pp. 379-396, doi: 10.1080/19460171.2014.957056.

Learmonth, M., Harding, N., Gond, J.-P. and Cabantous, L. (2016), "Moving critical performativity forward", Human Relations, Vol. 69 No. 2, pp. 251-256.

Lowe, A. (2001), "After ANT. An illustrative discussion of the implications for qualitative accounting case research", Accounting, Auditing and Accountability Journal, Vol. 14 No. 3, pp. 327-351.

Lyotard, J.-F. (1984), [1979], The Postmodern Condition: A Report on Knowledge, Bennington, G. and Massumi, B. (Eds) Manchester University Press, Manchester.

McLaren, J. and Appleyard, T. (2020), "Improving accountability for farm animal welfare: the performative role of a benchmark device", Accounting, Auditing and Accountability Journal, Vol. 33 No. 1, pp. 32-58.

MacKenzie, D. (2006a), An Engine, Not a Camera, MIT Press, Cambridge, MA.

MacKenzie, D. (2006b), "Is economics performative? Option theory and the construction of derivatives markets", Journal of the History of Economic Thought, Vol. 28 No. 1, pp. 29-55.

Marti, E. and Gond, J.-P. (2018), "When do theories become self-fulfilling? Exploring the boundary conditions of performativity”, Academy of Management Review, Vol. 43 No. 3, pp. 487-508.

Matilal, S. and Adhikari, P. (2020), "Accounting in Bhopal: making catastrophe”, Critical Perspectives on Accounting, Vol. 72, available at: doi.org/10.1016/j.cpa.2019.102123

Mauthner, N.S. (2019), "Toward a posthumanist ethics of qualitative research in a big data era", American Behavioral Scientist, Vol. 63 No. 6, pp. 669-698.

Messner, M. (2009), "The limits of accountability”, Accounting, Organizations and Society, Vol. 34 No. 8, pp. 918-938.

Miller, P. (1992), “Accounting and objectivity: the invention of calculating selves and calculable spaces”, Annals of Scholarship, Vol. 9 No. 2, pp. 61-86. 
QRAM 19,2

Miller, P. and O'Leary, T. (1987), “Accounting and the construction of the governable person”, Accounting, Organizations and Society, Vol. 12 No. 3, pp. 235-265.

Miller, P. and Power, M. (2013), "Accounting, organizing and economizing: connecting accounting research and organizational theory”, Academy of Management Annals, Vol. 7 No. 1, pp. 555-603.

Minnaar, R., Vosselman, E., Van Veen-Dirks, P. and Zahir-Ul-Hassan, K. (2017), "A relational perspective on the contract-control-trust nexus in interfirm relationships", Management Accounting Research, Vol. 34, pp. 30-41.

Modell, S. (2020), "For structure: a critical realist critique of the use of actor-network theory in critical accounting research", Accounting, Auditing and Accountability Journal, Vol. 33 No. 3, pp. 621-640.

Mouritsen, J. and Kreiner, K. (2016), “Accounting, decisions and promises”, Accounting, Organizations and Society, Vol. 49, pp. 21-31.

Mouritsen, J., Hansen, A. and Hansen, C.O. (2009), "Short and long translations: management accounting calculations and innovation management", Accounting, Organizations and Society, Vol. 34 Nos 6/7, pp. 738-754.

Nyberg, D. (2009), "Computers, customer service operatives and cyborgs: intra-actions in call centres", Organization Studies, Vol. 30 No. 11, pp. 1181-1199.

Orlikowski, W.J. and Scott, S.V. (2014), "What happens when evaluation goes online? Exploring apparatuses of valuation in the travel sector", Organization Science, Vol. 25 No. 3, pp. 868-891.

Power, M. (2018), "Accounting, boundary-making and organizational permeability", Research in the Sociology of Organizations, Vol. 57, pp. 31-53.

Power, M. (2021), "Modelling the microfoundations of the audit society: organizations and the logic of the audit trail", Academy of Management Review, Vol. 46 No. 1, pp. 6-32.

Qu, S.Q. and Cooper, D.J. (2011), "The role of inscriptions in producing a balanced scorecard", Accounting, Organizations and Society, Vol. 36 No. 6, pp. 344-362.

Revellino, S. and Mouritsen, J. (2015), "Accounting as an engine: the performativity of calculative practices and the dynamics of innovation”, Management Accounting Research, Vol. 28, pp. 31-49.

Revellino, S. and Mouritsen, J. (2017), "Ex-citable accounting and the development of pervasive innovation", Qualitative Research in Accounting and Management, Vol. 14 No. 4, pp. 448-466.

Roberts, J. (2009), "No one is perfect: the limits of transparency and an ethic for 'intelligent' accountability", Accounting, Organizations and Society, Vol. 34 No. 8, pp. 957-970.

Roberts, J. and Jones, M. (2009), “Accounting for self interest in the credit crisis", Accounting, Organizations and Society, Vol. 34 Nos 6/7, pp. 856-867.

Robson, K. (1991), "On the arenas of accounting change: the process of translation”, Accounting, Organizations and Society, Vol. 16 Nos 5/6, pp. 547-570.

Robson, K. (1992), “Accounting numbers as 'inscription'; action at a distance and the development of accounting", Accounting, Organizations and Society, Vol. 17 No. 7, pp. 685-708.

Ruff, K. (2021), "How impact measurement devices act: the performativity of theory of change, SROI and dashboards", Qualitative Research in Accounting and Management, Vol. 18 No. 3, doi: 10.1108/QRAM-02-2019-0041.

Savage, A.A. (1995), "A postmodern perspective on the scientific status of accounting: a research note", De Ratione, Vol. 9 No. 1, pp. 1-8.

Schaefer, S.M. and Wickert, C. (2016), "On the potential of progressive performativity: definitional purity, re-engagement and empirical points of departure”, Human Relations, Vol. 69 No. 2, pp. 215-224.

Schatzki, T.R. (2002), The Site of the Social: A Philosophical account of the Constitution of Social Life and Change, PA State University Press, University Park, PA.

Searle, J. (1969), Speech Acts: An Essay in the Philosophy of Language, Cambridge University Press, Cambridge. 
Skærbæk, P. and Tryggestad, K. (2010), "The role of accounting devices in performing corporate strategy", Accounting, Organizations and Society, Vol. 35 No. 1, pp. 108-124.

Spicer, A., Alvesson, M. and Kärreman, D. (2009), "Critical performativity: the unfinished business of critical management studies", Human Relations, Vol. 62 No. 4, pp. 537-560.

Spicer, A., Alvesson, M. and Kärreman, D. (2016), "Extending critical performativity", Human Relations, Vol. 69 No. 2, pp. 225-249.

Themsen, T.N. and Skærbæk, P. (2018), "The performativity of risk management frameworks and technologies: the translation of uncertainties into pure and impure risks", Accounting, Organizations and Society, Vol. 67, pp. 20-33.

Van Erp, E., Roozen, F. and Vosselman, E. (2019), "The performativity of a management accounting and control system: exploring the dynamic relational consequences of a design", Scandinavian Journal of Management, Vol. 35 No. 4, available at: doi.org/10.1016/j.scaman.2019.101077

Visser, L.M. and Davies, O.E. (2021), "The becoming of online healthcare through entangled power and performativity: a posthumanist agential realist perspective", Organization Studies, Vol. 42 No. 12, pp. 1-21, available at: doi.org/10.1177/0170840621997616

Vollmer, H. (2019), "Accounting for tacit coordination: the passing of accounts and the broader case for accounting theory", Accounting, Organizations and Society, Vol. 73, pp. 15-34.

Vollmer, H., Mennicken, A. and Preda, A. (2009), "Tracking the numbers: across accounting and finance, organizations and markets", Accounting, Organizations and Society, Vol. 34 No. 5, pp. 619-637.

Vosselman, E. (2014), “The 'performativity thesis' and its critics: towards a relational ontology of management accounting", Accounting and Business Research, Vol. 44 No. 2, pp. 181-203.

Warren, L. and Seal, W. (2018), "Using investment appraisal models in strategic negotiation: the cultural political economy of electricity generation", Accounting, Organizations and Society, Vol. 70, pp. 16-32.

Wickert, C. and Schaefer, S.M. (2015), "Towards a progressive understanding of performativity in critical management studies", Human Relations, Vol. 68 No. 1, pp. 107-130.

\section{Corresponding author}

Ed Vosselman can be contacted at: e.vosselman@fm.ru.nl

For instructions on how to order reprints of this article, please visit our website: 